\title{
EFFECT OF APPLICATION METHODS OF TWO NEONICOTINOID PESTICIDES ON SPRAY COVERAGE SPECTRUM AND REDUCTION PERCENT OF WHEAT APHID, RHOPALOSIPHUM PADI AT SHARQIA GOVERNORATE
}

\author{
AMMAR, A. E. ${ }^{1}$, E.M.S. MOKBEL ${ }^{2}$ and WALAA M. SALLOUM ${ }^{1}$ \\ 1. Department of Spray Technology, Plant Protection Research Institute. Agriculture \\ Research Center \\ 2. Central Agricultural Pesticides Laboratory, Agriculture Research Center, 12618 \\ Giza, Egypt
}

(Manuscript received 27 December 2017)

\begin{abstract}
$\mathrm{I}$ $\mathrm{n}$ the current study, two equipment were used to control wheat Aphid, Rhopalosiphum padi. The first equipment, Knapsack sprayer (3WDB) with battery charge and flat fan nozzle. The second equipment, Knapsack motor sprayer (IE34F) with hydraulic pump and spray gun at New Salhyia city, Sharqia Governorate. The present study aimed to determine the effects of application method on initial and late biological efficacy of imidacloprid and dinotefuran (belong to neonicotinoid) against wheat aphid. Results in two seasons (2016 \& 2017) indicated that, IE34F Motor sprayer (as high volume sprayer) showed less initial efficacy compared with 3WDB Power sprayer (as medium sprayer volume). Although the imidacloprid pesticide gives high efficacy compared with dinotefuran pesticide. The main obtained difference was Imidacloprid with 3WDB Power sprayer gave the highest efficacy with a significant difference compared with dinotefuran with IE34F Motor sprayer.

Key words: Wheat Aphid, Ground Equipment, Neonicotinoid, Qualitative, Biological Analysis
\end{abstract}

\section{INTRODUCTION}

Wheat (Triticum sativum L.) is the main cereal crops with the largest area under winter cultivation in Egypt. Wheat greatly affects the economic and social stability of the country, because it represents the essential component in bread production (Elhamid, 2014). Yield of wheat affected by several abiotic and biotic factors, including the incidence of insect pests and diseases (Khan, et. al., 2012).

Many insect pests infest wheat and cause enormous damage; Aphid is a major obstacle posing wheat production in Egypt. Aphid causes yield losses throughout either directly by sap-sucking of the plants or indirectly through viruses' diseases transmission. The Bird cherry oat Aphid, (Rhopalosiphum padi), was found as the greatest abundant Aphid species in Egyptian wheat fields (El-Heneidy, 1994). Due to the ability of Aphid to multiply very rapidly under optimum conditions; Aphids considered as a dangerous pest of the wheat crop. So, insecticides application is the essential mean to control Aphids. Various types of insecticides including neonicotinoids 
have been recommended to control wheat Aphid (Dogimont, et. al., 2010; Zuo, et. al., 2016).

Neonicotinoids are the fast upward class of insecticides with high efficiency in controlling sucking insect pests including Aphid. Neonicotinoids showed desire characteristics besides efficiencies such as safety, broad insecticidal spectrum, translaminar activity, long duration, no cross-resistance to conventional insecticides and high versatile use rather than other insecticides classes (Jeschke, et. al., 2011). The insecticidal effect of droplets sprayed is dependent not only on droplet diameter but also on droplet number $/ \mathrm{cm}^{2}$ and concentration of active ingredient of used insecticides (Elbert, et. al., 1999). The previous studies suggest that the optimal droplet size varies according to insecticide, target pest, and application method. Therefore, the relationship between the droplet sizes of an insecticide and the mortality of the target pest needs to be determined on a case-by-case basis in order to achieve optimal control of a target pest. So, ground spraying equipment could affect on toxicant efficacy, through affecting the spraying parameters, such as volume mean diameter (VMD) which greatly affects on mortality and residual effects of permethrin against second instar Plutella xylostella L. (Omar, et. al., 1991). Similar findings were reported with deltamethrin and chlorpyrifos against Myzus persicae (Sulzer) (Thacker, et. al.,1995).

The present work aimed to determine the effects of two application methods and droplet sizes distribution on initial and late efficacy of imidacloprid and dinotefuran (belong to neonicotinoids) against Rhopalosiphum padi on wheat, at New Salhyia city during two successive seasons.

\section{MATERIALS AND METHODS}

\subsection{Pesticides used}

The two tested insecticides were Imidacloprid (Confidor 20\% SC., Bayer CropScience, Germany) and Dinotefuran (Ocean 20\% SG., Mitsu Chemicals Agro. Inc., Japan)

\subsection{Field experiments}

Field experiments were conducted during the growing wheat seasons of 2016 and 2017 at New Salhyia city, Sharqia Governorate to evaluate the efficiency of the tested insecticides applied with two equipment against the wheat aphid, Rhopalosiphum padi. In this region, resistance problems have not observed in past years, and recognized that neonicotinoids insecticides still maintained the pest under acceptable levels. An area of about 12 kirate $\left(2000 \mathrm{~m}^{2}\right)$ of wheat variety 'Gomaiza 10' was used. The experimental area was divided into four plots $\left(100 \mathrm{~m}^{2}\right.$ for each). The 
four replicates of the four treatments beside the control were arranged in completely randomized block design. Wheat was treated on March after 3 months from cultivation, when the plant was about one meter height.

Samples of 25 leafs were chosen at random from each replicate before treatments and at $1,3,5,7,9,11$ and 14 days after pesticides application. The number of aphid was counted. Percentage of reduction of the insect population was calculated according to Henderson and Tilton (1955).

\subsection{Utilize Ground Equipment}

Two sprayers were evaluated in this study and their properties illustrates in table 1. 1-Knapsack sprayer: 3WBD power sprayer (50.0 Liter/Fed.). It is consists of a barrel, a base, a battery, a mini pump, charger, spraying system, (rubber tubes, switch, spraying rod nozzle), a strip, castors, etc.

2-Knapsack motor sprayer: it is conducted with sprayer pump was calibrated to deliver (74.0 Liter/fed.).

Table 1. Characteristic parameters of the hand held Knapsack sprayer and the Knapsack motor sprayer

\begin{tabular}{|l|c|c|}
\hline Parameters & Knapsack sprayer 3WDB & Knapsack motor sprayerIE34F \\
\hline Nozzle type & Flat fan & Spray gun \\
\hline Produced Country & China & China \\
\hline Total tank capacity(Liter) & $20 \quad$ Hydraulic \\
\hline Atomization Type & $50 \quad$ Target Spray \\
\hline Spray volume (Liter/Fed.) & 2.4 & 74 \\
\hline Spraying Type & 1 & 3.2 \\
\hline Working speed (Km/h.) & 3 & 1 \\
\hline Nozzle numbers & 2 & 3 \\
\hline Pressure (bar) & 0.940 & 4 \\
\hline Swath width (m.) & \multicolumn{2}{|c|}{ Down Wind(North-East) } \\
\hline Flow rate (L./ min.) & Medium Volume & 0.5 \\
\hline Spray height (m.) & \multicolumn{2}{|c|}{ High volume } \\
\hline Wind Direction & \multicolumn{2}{|c|}{} \\
\hline Spraying pattern & \multicolumn{2}{|c|}{} \\
\hline
\end{tabular}

- $\quad$ Temperature: $25^{\circ} \mathrm{C}$

- $\quad$ Relative humidity: $80 \%$

- $\quad$ Wind speed $2 \mathrm{~m} / \mathrm{sec}$.

\subsection{Sampling line and field trail}

The sampling line consisted of 5 wired fixed on diagonal lines inside each treatment to collect sprayed chemicals between plants. Water sensitive cards ( $2.5 \times 5$ $\mathrm{cm}$ ) were distributed on wheat plants at distance of one meter at three levels upper, middle and lower to determine the actual spray coverage on the treated plants. All cards were numbered, collected and transferred carefully to the laboratory for measurement and calculation of the deposited droplets number. Size of droplets were 
measured by using strobins lens ${ }^{\times} 15$ (Abo Amer 1993). The calibration programme was suggested according to (Gabir, et. al.. 1982)

\subsection{Statistical analysis}

Evaluation treatments bioefficacy was conducted as reduction percentage according to Henderson \& Tilton (1955). Analysis of variance (ANOVA) using the statistic software SBSS version 19 was conducted. Means of different treatments were separated by LSD (least significant difference) at $P=0.05$

\section{RESULTS}

\subsection{Qualitative analysis of droplets distribution on two ground techniques for controlling wheat Aphid}

Data presented in table (2) indicated that 3WDB Power sprayer at spraying volume 50.0 L/Fed. with Confidor (imidacloprid) gave volume mean diameter ranged from 140:187 $\mu$ with a mean of $164 \mu$. The droplet numbers ranged from 22:82 droplets $/ \mathrm{cm}^{2}$ with mean 56.0 droplets $/ \mathrm{cm}^{2}$ and the lost spraying on ground was $5.1 \%$. While it gave volume mean diameter ranged from $147: 193 \mu$ with a mean of $168.0 \mu$ with ocean pesticide. The droplet numbers ranged from $18: 79$ droplets $/ \mathrm{cm}^{2}$ with mean 52.0 droplets $/ \mathrm{cm}^{2}$ and the lost spraying on ground was $3.1 \%$. The above mentioned data indicated that the confidor pesticide gave more satisfactory results when compared with ocean pesticide using the 3WDB power sprayer.

In the case of IE34F Motor sprayer (spraying volume $74.0 \mathrm{~L} / \mathrm{Fed}$ ), data in Table 2 showed that, Confidor volume mean diameter ranged from 95:130 $\mu$ and the mean diameter was $115.3 \mu$. The droplet numbers ranged from 37:135 droplets/cm2 with mean of 91 droplets $/ \mathrm{cm}^{2}$ and the lost spraying on ground was $6 \%$. While with Ocean, the volume means diameter ranged from $97: 135 \mu$ with a mean of $120.0 \mu$. The droplet numbers ranged from 33:131 droplets $/ \mathrm{cm}^{2}$ with mean number 86.0 droplets $/ \mathrm{cm}^{2}$ and the lost spraying on ground was $5.8 \%$. So, the confidor gave more high results if compared with ocean by using IE34F sprayer. Its appear that the power of spray gave more high efficacy than the motor sprayer, because its produced the optimum droplets size for the aimed against target pest with the sufficient droplets numbers $/ \mathrm{cm}^{2}$. 
Table 2. Spray coverage means as obtained from two sprayers by using two insecticides on wheat plants for controlling wheat Aphids during seasons 2016\&2017

\begin{tabular}{|c|c|c|c|c|c|c|c|c|c|c|c|c|c|}
\hline Insecticides & Sprayers & \multicolumn{2}{|c|}{ Upper } & \multicolumn{2}{|c|}{ Middle } & \multicolumn{2}{|c|}{ Lower } & \multicolumn{3}{|c|}{ Average } & \multicolumn{3}{|c|}{ Lost spray on ground } \\
\hline \multirow{2}{*}{$\begin{array}{c}\text { Confidor } \\
200 \mathrm{ml} / \mathrm{fed} \text {. }\end{array}$} & $\begin{array}{l}\text { 3WDB } \\
\text { Power } \\
\text { sprayer }\end{array}$ & 187 & 82 & 163 & 65 & 140 & 22 & 163.3 & 56.3 & 94.9 & 138 & 9 & 5.1 \\
\hline & $\begin{array}{l}\text { IE34F } \\
\text { Motor } \\
\text { sprayer }\end{array}$ & 130 & 135 & 121 & 100 & 95 & 37 & 115.3 & 90.7 & 94 & 63 & 17 & 6 \\
\hline $\begin{array}{c}\text { Ocean } 200 \\
\text { gm/fed }\end{array}$ & $\begin{array}{l}\text { 3WDB } \\
\text { Power } \\
\text { sprayer }\end{array}$ & 193 & 79 & 165 & 60 & 147 & 18 & 168.3 & 52.3 & 96.9 & 140 & 5 & 3.1 \\
\hline
\end{tabular}

VMD: Volume mean diameter

$\mu$ : Micron

$\mathrm{N} / \mathrm{cm}^{2}$ : Number of droplets $/ \mathrm{cm}^{2}$

N\%: Reduction percent of Aphid population 


\subsection{The efficiency of different treatments throughout two seasons}

Results presented in table (3) showed the initial effect of the tested treatments throughout two successive seasons. Application treatments with 3WDB Power sprayer proved the highest initial performance and proved significant differences than IE34F Motor sprayer (After $24 \mathrm{Hrs}$.). In the first season reduction percent was 93.3 and $90.4 \%$ for Confidor and Ocean, respectively. The same trend was obtained in the second season with reduction percent of 98 and $93.8 \%$ for Confidor and Ocean, respectively. In contrast, IE34F Motor sprayer showed less initial efficacy compared with 3WDB Power sprayer. In the first season the reduction percent was 87.4 and $63.9 \%$ for Confidor and Ocean, respectively. Similar results were obtained in the second season with Confidor and Ocean which proved reduction percent of 91.5 and $84.1 \%$, respectively.

Residual activity of the tested treatments showed that residual efficacy (throughout 3-14 day) proved very high efficiency with 3WDB Power sprayer. In the first season, treatments achieved reduction percent of 96.8 and 96.13 for Confidor and Ocean, respectively. Similar results were obtained in the second season with reduction percent of 99.31 and $98.53 \%$ for Confidor and Ocean, respectively. In case of IE34F Motor sprayer residual activity of the tested treatments showed similar results trend except with Ocean which gave the least residual efficacy with reduction percent of 79.41 and 88.21 for the first and second season, respectively.

In the first season, residual efficacy differences between all treatments were insignificant except for IE34F Motor sprayer ocean treatment. While, in the second season, treatments with 3WDB Power sprayer had a significant differences than treatments with IE34F Motor sprayer. 
Table 3. Reduction Percent of Aphid Numbers (Rhopalosiphum padi) after treated with pesticides (Confidor $\&$ Ocean) by used two type's sprayer at season (2016 \& 2017)

\begin{tabular}{|c|c|c|c|c|c|c|}
\hline \multirow{2}{*}{\multicolumn{2}{|c|}{$\begin{array}{l}\text { Equipment } \\
\text { Spraying volume }\end{array}$}} & \multirow{2}{*}{\multicolumn{2}{|c|}{ Sprayer 3WDB }} & \multicolumn{2}{|c|}{ Motor IE34F } & \multirow{3}{*}{ L.S.D } \\
\hline & & & & & ffed. & \\
\hline \multicolumn{2}{|c|}{$\begin{array}{l}\text { Pesticides and } \\
\text { dosages }\end{array}$} & $\begin{array}{l}\text { Confidor } 200 \\
\mathrm{ml} / \text { fed. }\end{array}$ & $\begin{array}{l}\text { Ocean } 200 \\
\text { gm/fed. }\end{array}$ & $\begin{array}{l}\text { Confidor } 200 \\
\mathrm{ml} / \text { fed. }\end{array}$ & $\begin{array}{l}\text { Ocean } 200 \\
\text { gm/fed. }\end{array}$ & \\
\hline \multicolumn{7}{|c|}{ Season 2016} \\
\hline \multirow{7}{*}{ 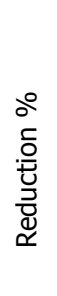 } & $24 \mathrm{H}$ & $93.3 \pm 0.64 a$ & $90.4 \pm 1.76 \mathrm{~b}$ & $87.4 \pm 1.79 c$ & $63.9 \pm 1.62 d$ & 2.16 \\
\hline & 3 days & $96.6 \pm 0.85 a$ & $91.6 \pm 1.57 \mathrm{~b}$ & $99 \pm 0.58 c$ & $81.5 \pm 1.77 d$ & 1.83 \\
\hline & 5 days & $99.6 \pm 0.26 a$ & $98.6 \pm 0.55 b$ & $99.9 \pm 0.07 a$ & $92.9 \pm 0.94 c$ & 0.80 \\
\hline & 7 days & $98.8 \pm 0.31 a$ & $98.3 \pm 0.21 a$ & $98 \pm 0.65 a$ & $79 \pm 2.12 b$ & 1.59 \\
\hline & 9 days & $98.8 \pm 0.47 a$ & $97.8 \pm 0.74 a$ & $96.7 \pm 0.68 a$ & $76.8 \pm 2.17 \mathrm{~b}$ & 1.73 \\
\hline & 11 days & $93.8 \pm 0.72 \mathrm{a}$ & $95.4 \pm 0.73 b$ & $93.6 \pm 0.77 a$ & $73.2 \pm 0.97 c$ & 1.14 \\
\hline & 14 days & $93.2 \pm 0.64 a$ & $95.1 \pm 0.59 b$ & $92.8 \pm 0.69 a$ & $73.1 \pm 1.15 \mathrm{c}$ & 1.13 \\
\hline \multicolumn{2}{|c|}{$\begin{array}{l}\text { Residual } \\
\text { efficacy }\end{array}$} & $96.3 \pm 1.07 a$ & $95.3 \pm 1.23 a$ & $95.3 \pm 1.65 a$ & $77.2 \pm 3.37 b$ & 2.90 \\
\hline \multicolumn{7}{|c|}{ Season 2017} \\
\hline \multirow{7}{*}{ 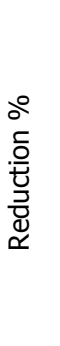 } & $24 \mathrm{H}$ & $98 \pm 0.18 a$ & $93.8 \pm 0.96 b$ & $91.5 \pm 2.26 \mathrm{~b}$ & $84.1 \pm 2.69 c$ & 2.58 \\
\hline & 3 days & $99.3 \pm 0.47 a$ & $96 \pm 0.66 b$ & $97.5 \pm 0.57 c$ & $92.7 \pm 1.02 \mathrm{~d}$ & 1.007 \\
\hline & 5 days & $99.3 \pm 0.25 a$ & $99.9 \pm 0.10 a$ & $97.5 \pm 0.28 b$ & $94.4 \pm 01.01 c$ & 0.77 \\
\hline & 7 days & $99.6 \pm 0.26 a$ & $99.4 \pm 0.35 a$ & $98.9 \pm 0.52 a$ & $89.3 \pm 1.41 b$ & 1.11 \\
\hline & 9 days & $99.5 \pm 0.20 a$ & $99.2 \pm 0.38 a$ & $98.6 \pm 0.91 a$ & $86.1 \pm 2.15 b$ & 1.68 \\
\hline & 11 days & $99.2 \pm 0.37 a$ & $98.8 \pm 0.58 a$ & $98.2 \pm 0.59 a$ & $84.3 \pm 1.03 c$ & 0.98 \\
\hline & 14 days & $98.6 \pm 0.50 a$ & $97.9 \pm 0.40 \mathrm{a}$ & $96.8 \pm 0.83 b$ & $82.9 \pm 0.73 c$ & 0.91 \\
\hline \multicolumn{2}{|c|}{$\begin{array}{l}\text { Residual } \\
\text { efficacy }\end{array}$} & $99.1 \pm 0.21 a$ & $97.9 \pm 0.83 a$ & $97.0 \pm 0.95 a$ & $87.7 \pm 1.70 c$ & 1.51 \\
\hline
\end{tabular}

* The mean difference is significant at the 0.05 level

* The same letters means that is no significant difference

* The different letters means that is a significant difference

\section{DISCUSSION}

Our results revealed that Confidor was superior in either initial or residual efficacy in the two years experiments. The efficacy of the tested treatments affected seriously by the used equipment. With the same insecticide, 3WDB Power sprayer was more superior with significant difference when compared with IE34F Motor sprayer in all treatments in both the two years of experiments. These findings are in agreement with (Horowitz, et. al., 1998) they reported that the bioefficacy of the commercial neonicotinoid insecticides is strongly influenced by the method of application. In Aphids, the application method significantly influenced green peach Aphid and potato Aphid control by neonicotinoid insecticides (Palumbo, et. al.. 1999). Residual activity of the tested neonicotinoid compounds was higher than the initial efficacy. Because of the bioefficacy of the plant metabolites (the nitroso and olefin metabolites) were more active against Aphids (Nauen, et. al., 1999 a, b) 
With the same insecticide, 3WDB Power sprayer produced more large volume mean diameter than IE34F Motor sprayer. The present results indicated that the larger droplets originated from 3WDB Power sprayer were more effective than the smaller droplets from IE34F Motor sprayer. The produced large droplets exhibited the greatest bioefficacy as a result to sufficiently adhere to insect body and difficulty borne away from the insect body because of their greater inertia forces (Sugiura, et. al.. 2011). Droplet sizes ranging from 100 to $150 \mu$ might have a lower potential for spray drift than applications with smaller droplet sizes (Boina, et. al.., 2012). Generally, laboratory experiments exhibit that small droplet showing great efficacy than small droplets.

The present study demonstrated that spray solution with low volume and droplet size range $(165-170 \mu)$ which produced by 3WDB Power sprayer was more efficient than high volume with smaller droplet size (115-120 $\mu)$ originated from IE34F motor sprayer. Our study contributes to understanding the effect of droplet size of two neonicotinoid insecticides spray solution for controlling the wheat Aphid and clarifies the importance of investigating the relationship between pesticides efficacy against a pest and droplet size distribution of the products.

\section{REFERENCES}

1. Abou-Amer A.M. 1993. Spray Spectrum of Insecticide deposits on the Cotton Canopy After Using Different Spraying Techniques. Ph.D. Thesis, Fac. of Agric., Cairo University, Egypt, page 59.

2. Boina D. R.; Salyani M.; Tiwari S., Pelz-Stelinski K., and Stelinski L. L. 2012. Spray Droplet Size Affects Efficacy of Fenpropathrin Against Asian Citrus Psyllid. Pesticide Formulations and Delivery Systems: STP 1558, DOI:10.1520/STP104310

3. Dogimont C.; Bendahmane A.; Chovelon V. and Boissot N. 2010. Host Plant Resistance to Aphids in Cultivated Crops: Genetic and Molecular Bases, and Interactions with Aphid Populations. Comptes Rendus Biologies, 333(6-7): 566573. doi:10.1016/j.crvi.2010.04.003

4. Elbert T.A; Taylor R.A.J.; Downer R.A. and Hall F.R. 1999. Deposit structure and efficacy of pesticide application. 1: Interactions between deposit size, toxicant concentration and deposit number. Pestic. Sci 55: 783-792.

5. Elhamid E.M.A.; Sadak M. S.andTawfik M.M. 2014. Alleviation of Adverse Effects of Salt Stress in Wheat Cultivars by Foliar Treatment with Antioxidant 2-Changes in Some Biochemical Aspects, Lipid Peroxidation, Antioxidant Enzymes and Amino Acid Contents. Agricultural Sciences, 5(13): 1269-1280.

6. El-Heneidy A. H. 1994. Efficacy of Aphidophagous Insects Against Aphids at Wheat Fields in Egypt. Egypt. J. Biol. Pest Control 4(2): 113-123. 
7. Gabir I. ;Zidan Z. H.; Attalah E. and Hindy M.A. 1982. Calibration and Evaluation of the Performance of Certain Hdraulic Nozzle Types Under Laboratory Conditions. Res. Bull. 1738 Fac. Agric. Ain Shams Univ. page 19.

8. Henderson C.F. and Tilton E.W. 1955. Test with Acaricides Against the Brown Wheat Mite. J. Econ. Ent., 48: 157-161.

9. Horowitz A.R.; Mendelson Z.; Weintraub P.G. and Ishaaya I. 1998. Comparative Toxicity of Foliar and Systemic Applications of Acetamiprid and Imidacloprid Against the Cotton Whitefly, Bemisia tabaci (Hemiptera: Aleyrodidae). Bull Entomol Res 88:437-442.

10. Jeschke P.; Nauen R.; Schindler M. and Elbert A. 2011. Overview of the Status and Gobal Strategy for Neonicotinoids, J Agric Food Chem 59: 2897-2908.

11. Khan A. M.; Khan A.A.; Afzal M. and Iqbal M.S. 2012. Wheat Crop Yield Losses Caused by the Aphids Infestation. J Biofertil. Biopestici. 3(4): 1-3.

12. Nauen R., Tietjen K.; Wagner K. and Elbert A. 1999. Efficacy of Plant Metabolites of Imidacloprid Against Myzus persicae and Aphis gossypii (Homoptera: Aphididae). Pest Manag. Sci., 52: 53-57.

13. Nauen R.; Reckmann U.; Armborst S.; Stupp H. and Elbert A. 1999. Whitefly Active Metabolites of Imidacloprid: Biological Efficacy and Translocation in Cotton Plants. Pest Manag. Sci 55: 265-271.

14. Omar D. and Matthews G. A. 1991. "Influence of Formulation and Spray Droplet Size upon the Persistence of Permethrin Deposits on Brussels Sprouts Leaves," Crop Protection, 10: 41-44.

15. Palumbo J.; Mullis C., Reyes F.; Amaya A. and Ledesma L.1999. Application and Timing of Insecticides for Aphid Management in Head Lettuce, in The University of Arizona College of Agriculture 1999 Vegetable Report. College of Agriculture, The University of Arizona, Tucson, AZ, pp. 94-107.

16. Sugiura M.; Horibe Y.; Kawadab H. and Takagib M. 2011. Effect of Different Droplet Size on the Knockdown Efficacy of Directly Sprayed Insecticides. Pest Manag. Sci; 67: 1115-1123.

17. Thacker J. R. M.; Young R. D. F.; Stevenson S. and Curtis D. J. 1995. "Effects of a Change in Pesticide Droplet Size on Topical Toxicity of Chlorpyrifos and Deltamethrin to Myzus persicae (Homoptera: Aphididae) and Nebria brevicollis (Coleoptera: Carabidae)," J. Econ. Entomol., 88: 1560-1565.

18. Tsuda S.; Nishibe I. and Shinjo G. 1987. Effect of the Diameter of Spray Droplets on the Insecticidal Efficacy of Oil-Based Aerosols. J Pestic. Sci 12: 483-489.

19. Zuo Y.; Wang K.; Zhang M.; XiongPeng X.; Piñero J. C.andMaohua C. 2016. Regional Susceptibilities of Rhopalosiphum padi (Hemiptera: Aphididae) to Ten Insecticides Florida Entomologist —99 (2): 269-275. 


\title{
تأثير طرق تطبيق الرش لإثنين من مبيدات النيونيكوتينويد علي طيف غطاء الرش

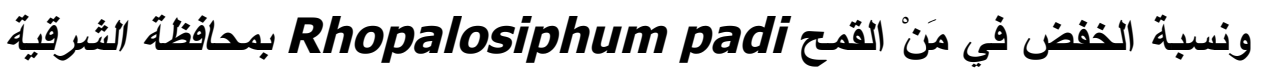

\author{
عبدالمجيد السبد عمار'، السيد محمد سليمان مقبل'، ولاء محمود سلوم

$$
\begin{aligned}
& \text { ا ـ معهد بحوث وقاية النباتات - مركز البحوث الزراعية -الدقي - الجيزة } \\
& \text { r ا . الدعهل المركزي للمبيدات- مركز البحوث الزراعية -الدقي - الجيزة }
\end{aligned}
$$

في هذه الدراسة نم استخدام نوعين من الآلات الأرضية لمكافحة آفة مَنْ القمح

Rhopalosiphum padi

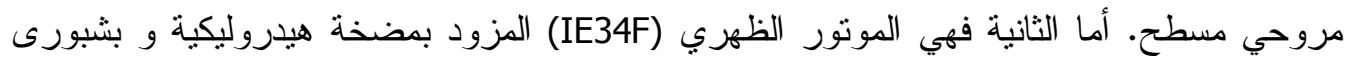
ذو مخروط أجوف. و قد أجريت التجارب في مدينة الصالحية الجديدة بمحافظة الثرقية. تهدف هذه الدراسة إلي تقدير تأثثر طريقة النطبيق علي الفعالية البيولوجية الفوربة و الأثر

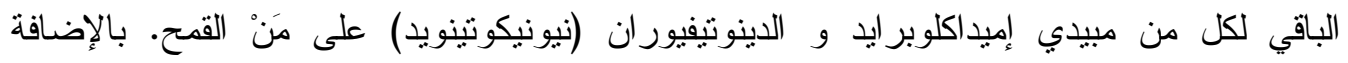
لتوضيح تأثثر طيف غطاء الرش على فاعلية المبيدات المستخدمة. أظهرت النتائج في كلا الموسمين

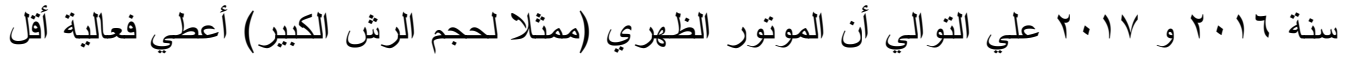
بالمقارنة بالرشانثة اليدوية الظهرية (التي تمنل حجم الرش المتوسط) في حين حقق مبيد إيميداكلوبر ايد كفاءة أعلى بالمقارنة بمبيد الدينوتيفيوران. النتيجة الرئيسية تشئير إلي أنهائه مبيد

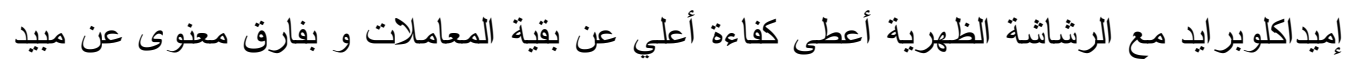

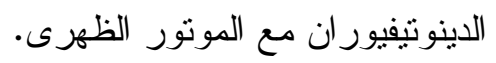

